\title{
Dominant Expression of Type III Hyperlipoproteinemia Pathophysiological Insights Derived from the Structural and Kinetic Characteristics of ApoE-1 (Lys ${ }^{146} \rightarrow$ Glu)
}

\author{
W. Alexander Mann, Peter Lohse, Richard E. Gregg, Rosemary Ronan, Jeffrey M. Hoeg, Loren A. Zech, \\ and H. Bryan Brewer, Jr. \\ Molecular Disease Branch, National Heart, Lung, and Blood Institute, National Institutes of Health, Bethesda, Maryland 20892
}

\begin{abstract}
Type III hyperlipoproteinemia is characterized by delayed chylomicron and VLDL remnant catabolism and is associated with homozygosity for the apoE-2 allele. We have identified a kindred in which heterozygosity for an apoE mutant, apoE-1 $\left(\right.$ Lys $^{146} \rightarrow$ Glu $)$, is dominantly associated with the expression of type III hyperlipoproteinemia. DNA sequence analysis of the mutant apoE gene revealed a single-point mutation that resulted in the substitution of glutamic acid (GAG) for lysine (AAG) at residue 146 in the proposed receptor-binding domain of apoE. The pathophysiological effect of this mutation was investigated in vivo by kinetic studies in the patient and six normal subjects, and in vitro by binding studies of apoE-1 ( Lys $^{146} \rightarrow$ Glu $)$ to LDL receptors on human fibroblasts and to heparin. The kinetic studies revealed that apoE-1 ( $\mathrm{Lys}^{146} \rightarrow$ Glu $)$ was catabolized significantly slower than apoE-3 in normals $(P<0.005)$. In the proband, the plasma residence times of both apoEs were substantially longer and the production rate of total apoE was about two times higher than in the control subjects. ApoE-1 ( Lys $^{146} \rightarrow$ Glu $)$ was defective in interacting with LDL receptors, and its ability to displace $L D L$ in an in vitro assay was reduced to $7.7 \%$ compared with apoE-3. The affinity of apoE-1 ( Lys $^{146} \rightarrow$ Glu $)$ to heparin was also markedly reduced compared with both apoE-2 (Arg ${ }^{158} \rightarrow$ Cys $)$ and apoE-3. These abnormal in vitro binding characteristics and the altered in vivo metabolism of apoE-1 $\left(\mathrm{Lys}^{146} \rightarrow\right.$ Glu $)$ are proposed to result in the functional dominance of this mutation in the affected kindred. (J. Clin. Invest. 1995. 96:11001107.) Key words: atherosclerosis • dysbetalipoproteinemia - in vivo kinetics - low density lipoprotein (apoB, apoE) receptor binding $\bullet$ heparin binding
\end{abstract}

\section{Introduction}

Human apoE is a constituent of several classes of plasma lipoproteins and plays an important role in modulating the catabolism of chylomicron and VLDL remnants by binding to LDL (apoB, apoE) and putative apoE (remnant) receptors on cell membranes (for reviews see references 1 and 2). The three major alleles of apoE code for the isoproteins apoE-2

Address correspondence to Dr. W. A. Mann, Medizinische Kern- und Poliklinik, Universitäts-Krankenhaus Eppendorf, Martinistr. 52, 20246 Hamburg, Germany. Phone: 49-40-4717 3917; FAX: 49-40-4717 4592. Received for publication 6 April 1994 and accepted in revised form 11 April 1995.

The Journal of Clinical Investigation, Inc.

Volume 96, August 1995, 1100-1107
(Arg ${ }^{158} \rightarrow$ Cys), apoE-3, and apoE-4(Cys ${ }^{112} \rightarrow$ Arg) (3-5). Structural defects of the apoE may result in the expression of type III hyperlipoproteinemia (HLP), ${ }^{1}$ which is characterized by an impaired chylomicron and VLDL remnant catabolism and the accumulation of cholesterol and apoE-enriched remnant particles (for reviews see references 6-8). Type III HLP is most frequently associated with homozygosity for apo $\mathrm{E}-2\left(\mathrm{Arg}^{158} \rightarrow \mathrm{Cys}\right)$, an isoprotein defective in its in vivo catabolism (9) and in vitro binding to LDL receptors (10). However, homozygosity for the $\Sigma$-2 allele is permissive for, but in 95\% of the cases not associated with, the development of type III HLP, and other hyperlipidemic factors appear to contribute to the manifestation of this disease $(11,12)$.

In contrast, five different apoE mutants have thus far been reported that are almost always associated with type III HLP, even in the heterozygous state, and have therefore been proposed to be inherited as autosomal dominant traits. ApoE2 (Lys ${ }^{146} \rightarrow$ Gln $)$ was originally identified in two independent individuals (13) and has since been observed in three additional kindreds (14). The double mutant apoE-3 (Cys ${ }^{112} \rightarrow$ Arg, $\mathrm{Arg}^{142} \rightarrow$ Cys ) was described in one family, and all six heterozygotes were dysbetalipoproteinemic, even at the age of 2 years $(15,16)$. Family studies in subjects with apoE-3(Cys ${ }^{112} \rightarrow$ Arg, duplication of residues $120-126$ or 121-127) identified 42 heterozygotes (17-20). All carriers of the mutated allele exhibited characteristics of type III HLP. Another mutant apoE, apoE-4 ( Glu $^{13} \rightarrow$ Lys, $\operatorname{Arg}^{145} \rightarrow$ Cys $)$, was originally observed in a 24-y-old homozygous female with severe type III HLP (21). Analysis of first-degree relatives indicated that the occurrence of apoE-4 (Glu ${ }^{13} \rightarrow$ Lys, Arg $^{145} \rightarrow$ Cys) is associated with an incomplete or partially dominant expression of a moderate form of this disease (22).

The mutant apoE-1 ( Lys $^{146} \rightarrow$ Glu $)$ also leads to a dominant expression of type III HLP in all five affected patients heterozygous for the mutated allele $(23,24)$. Since our initial description of this kindred, a second family with type III HLP due to the identical mutation has been identified in Japan (25).

In this study, we have determined the structural defect in the apoE-1 (Lys ${ }^{146} \rightarrow$ Glu ) gene and studied the functional implications of this mutation using in vivo kinetic studies in the proband and in normal subjects, and using in vitro binding assays with human fibroblasts and the proteoglycan heparin.

\section{Methods}

\section{Patient characterization}

The heterozygous proband of the apoE-1 ( Lys $^{146} \rightarrow$ Glu $)$ kindred has been described in detail previously (23). Briefly, he is a 50 -y-old white male

1. Abbreviations used in this paper: HLP, hyperlipoproteinemia; RT, residence time. 
Table I. Characteristics of the Study Subjects

\begin{tabular}{|c|c|c|c|c|c|c|c|c|c|}
\hline Subject & Age & Sex & Weight & ApoE & Cholesterol & Triglycerides & VLDL cholesterol & LDL cholesterol & HDL cholesterol \\
\hline & $y r$ & & $k g$ & & & & & $m g / d l$ & \\
\hline \multicolumn{10}{|l|}{ Normals } \\
\hline 1 & 23 & $\mathbf{F}$ & 74.0 & $3 / 3$ & 180 & 109 & 29 & 112 & 39 \\
\hline 2 & 19 & $\mathbf{F}$ & 71.7 & $3 / 3$ & 145 & 103 & 30 & 57 & 58 \\
\hline 3 & 21 & $\mathbf{M}$ & 70.9 & $3 / 3$ & 145 & 83 & 19 & 84 & 42 \\
\hline 4 & 20 & $\mathbf{F}$ & 57.8 & $3 / 3$ & 187 & 89 & 28 & 98 & 61 \\
\hline 5 & 21 & $\mathbf{M}$ & 77.9 & $3 / 3$ & 164 & 40 & 15 & 101 & 48 \\
\hline 6 & 22 & $\mathbf{M}$ & 81.5 & $3 / 3$ & 175 & 106 & 12 & 129 & 34 \\
\hline Proband & 50 & $\mathbf{M}$ & 77.0 & $1 / 3$ & 404 & 578 & 284 & 84 & 39 \\
\hline
\end{tabular}

with a history of hyperlipidemia and coronary artery disease. Physical findings include palmar xanthomas, tuberous xanthomas on his extremities, and xanthelasma. At the time of the study, he was without lipidlowering medications, and his plasma cholesterol value was $404 \mathrm{mg} / \mathrm{dl}$ with a VLDL cholesterol of $284 \mathrm{mg} / \mathrm{dl}$ (Table I). His total plasma apoE concentration was $50 \mathrm{mg} / \mathrm{dl}$, his apoE-1 ( Lys $^{146} \rightarrow \mathrm{Glu}$ ) level being $36.5 \mathrm{mg} / \mathrm{dl}$ and his apoE-3 level $13.5 \mathrm{mg} / \mathrm{dl}$. The ratio of apoE-1 to apoE-3 was determined by an isoelectric focusing gel of the probands plasma, followed by immunostaining with an apoE antibody and subsequent densitometric scanning (23).

\section{DNA isolation}

Genomic DNA was purified from white blood cells using an automated nucleic acid extractor (model 340A; Applied Biosystems Inc., Foster City, CA).

\section{Enzymatic amplification of genomic DNA}

$1 \mu \mathrm{g}$ each of genomic DNA from a control and the apoE-1 (Lys ${ }^{146} \rightarrow$ Glu)/apoE-3 subject was amplified with $5 \mathrm{U}$ of Taq DNA polymerase (Perkin-Elmer Corp., Norwalk, CT) as described (21), using an automated DNA thermal cycler (Perkin-Elmer Corp.). The reaction mixture was subjected to 30 cycles of denaturation at $94^{\circ} \mathrm{C}$ for $1 \mathrm{~min}$, annealing at $62^{\circ} \mathrm{C}$ for $1 \mathrm{~min}$, and polymerization at $72^{\circ} \mathrm{C}$ for $1 \mathrm{~min}$.

\section{DNA sequence analysis}

DNA amplified by the automated polymerase chain reaction was digested with the restriction endonucleases HindIII and EcoRI (New England BioLabs, Beverly, MA), according to the manufacturer's recommendations. Fragments were isolated from low melting point agarose (Bethesda Research Laboratories, Gaithersburg, MD) and subcloned into M13 vectors mp18 and mp19 (Bethesda Research Laboratories; reference 26). Sequencing was performed with the dideoxynucleotide chain termination method (27) using T7 DNA polymerase (Sequenase; United States Biochemical Corp., Cleveland, $\mathrm{OH}$ ).

\section{In vivo kinetic studies}

Study subjects. In addition to the patient described above, six healthy young adults, three males and three females, aged 19-23, were studied as controls. The six subjects had an apoE-3/3 phenotype, normal lipid levels for age and sex, normal fasting glucose concentrations, normal kidney, liver, and endocrine functions, and were taking no medications (Table I). All normal volunteers and the proband from the Harrisburg kindred were studied as in-patients at the Clinical Center of the National Institutes of Health and gave informed consent to the study protocol, which was approved by the Institute Review Board of the National Heart, Lung, and Blood Institute.

ApoE isolation. ApoE-1 ( $\mathrm{Lys}^{146} \rightarrow \mathrm{Glu}$ ) was isolated from the proband, whereas apoE-2 (Arg ${ }^{158} \rightarrow$ Cys) and apoE-3 were purified from individuals homozygous for the respective alleles. VLDL was obtained by preparative ultracentrifugation $(28,29)$ and delipidated with chloro- form/methanol (2:1). Heparin affinity and Sephacryl S-200 gel permeation chromatography were used to separate apoE from the other apos (30). Briefly, resolubilized VLDL was applied to a $2.5 \times 48-\mathrm{cm}$ column packed with heparin-Sepharose in $5 \mathrm{M}$ urea, $25 \mathrm{mM} \mathrm{NaCl}$, and $2 \mathrm{mM}$ sodium phosphate ( $\mathrm{pH} 7.7)$. Using a linear $\mathrm{NaCl}$ gradient (25-220 $\mathrm{mM}$ ) at $4^{\circ} \mathrm{C}$, apoE-1 ( $\mathrm{Lys}^{146} \rightarrow \mathrm{Glu}$ ) was recovered at a concentration of $50 \mathrm{mM} \mathrm{NaCl}$, while apoE-3 was eluted with $100 \mathrm{mM} \mathrm{NaCl}$. Finally, samples were dialyzed against $10 \mathrm{mM}$ ammonium bicarbonate.

Iodination. ApoE was iodinated by the iodine monochloride method (31), with previously described modifications (32). The amount of iodine monochlorid added was calculated to result in less than $1 \mathrm{~mol}$ iodine introduced per $2 \mathrm{~mol}$ of protein. The iodination efficiency ranged from 15 to $20 \%$. To remove potentially damaged apoE, radiolabeled apoE was reassociated with autologous plasma by incubation at $37^{\circ} \mathrm{C}$ for $30 \mathrm{~min}$. The plasma sample was adjusted to a density of 1.21 grams/ $\mathrm{ml}$ with potassium bromide. The supernatant was isolated by ultracentrifugation and dialyzed at $4^{\circ} \mathrm{C}$ against PBS. The recovery of radioactivity in the 1.21 -grams $/ \mathrm{ml}$ top fraction was $\sim 70 \%$ of the starting activity. Assuming that recovery of radioactivity corresponded to the recovery of apoE mass, the specific activities could be estimated with $\sim 7,500$ $\mathrm{cpm} / \mathrm{ng}$. HSA was then added to a final concentration of $1 \%$. The solution was sterilized by filtration through a $0.22-\mu \mathrm{m}$ filter (Millipore Corp., Bedford, MA), and testing was performed for pyrogens and sterility before injection.

Study protocol. The study subjects were placed on a defined isoweight diet ( $42 \%$ carbohydrate, $42 \%$ fat, $16 \%$ protein, $200 \mathrm{mg}$ cholesterol $/ 1,000 \mathrm{kcal}$, ratio polyunsaturated/saturated fat 0.2$) 3 \mathrm{~d}$ before the start of the study. $1 \mathrm{~d}$ before injection, the subjects began to receive $900 \mathrm{mg}$ potassium iodide per day given in equal doses three times a day with meals; this was continued through the end of the study. After the injection of ${ }^{131} \mathrm{I}$-apoE-3 and ${ }^{125} \mathrm{I}$-apoE-1 (Lys ${ }^{146} \rightarrow$ Glu $)$, blood samples were obtained after $10 \mathrm{~min}$, at $1,3,6,12,18$, and $24 \mathrm{~h}$, and every day until day 7 . The exact amount of apoE injected was not calculated but was estimated to be $<1 \%$ of the total pool size and thus did not significantly affect steady state conditions. Samples were collected into tubes containing $0.1 \% \mathrm{Na}_{2} \mathrm{EDTA}$, kept at $4^{\circ} \mathrm{C}$, and plasma was obtained by low-speed centrifugation at $2,000 \mathrm{rpm}$ for $30 \mathrm{~min}$. Sodium azide $(0.05 \%)$ and aprotinin (200 Kallikrein inhibitor $\mathrm{U} / \mathrm{ml}$; Boehringer Mannheim Biochemicals, Indianapolis, IN) were added to the plasma. Radioactivity was quantitated in a gamma counter (model Autogamma 5260; Packard Instruments Co., Downers Grove, IL).

Analytical methods. ApoE phenotypes were determined by isoelectric-focusing gel electrophoresis (33), and apoE levels were quantitated by radioimmunoassay (34). Plasma cholesterol and triglyceride concentrations were determined on an Abbott VPSS analyzer (Abbott Laboratories, North Chicago, IL). HDL cholesterol was measured after dextran sulfate precipitation of plasma (35). The other lipid and lipoprotein analyses were performed as published (36). The residence time (RT) was determined from the area under the plasma decay curves using the computer-assisted curve-fitting program SAAM 29 (37). The fractional 
catabolic rate is the reciprocal of the RT. Production rates were calculated according to the following formula: production rate $=(\mathrm{apoE}$ concentration $\times$ plasma volume $) /(\mathrm{RT} \times$ weight $)$. The plasma volume was determined by dividing the total radioactivity injected by the radioactivity per unit volume in a sample obtained $10 \mathrm{~min}$ after injection. Intergroup comparisons were performed using Student's $t$ test.

In vitro binding studies

$L D L$ displacement by apoE. To determine the LDL receptor-binding affinity of apoE-2, apoE-3, and the mutant apoE-1 ( Lys ${ }^{146} \rightarrow$ Glu $)$, their ability to displace radioiodinated LDL from receptors on normal human fibroblasts was quantitated. Normal fibroblasts were isolated and grown as previously described (38). On day 0 , cells were placed in 24-well plates (Costar Corp., Cambridge, MA) and maintained in growth medium (Eagle's minimal essential medium, $2 \mathrm{mM}$ glutamine, $10 \%$ [v/v] FCS). On day 6, the FCS was replaced with $10 \%$ lipoproteindepleted serum to upregulate LDL receptors. $48 \mathrm{~h}$ later the cells were chilled to $4^{\circ} \mathrm{C}$ for $20 \mathrm{~min}$. The medium was replaced with medium containing $2.5 \mu \mathrm{g}$ protein $/ \mathrm{ml}{ }^{125} \mathrm{I}-\mathrm{LDL}$ and apoE liposomes in concentrations of $1,2,4$, and $8 \mu \mathrm{g} / \mathrm{ml}$ (apoE-1 ( $\mathrm{Lys}^{146} \rightarrow \mathrm{Glu}$ ), apoE-2) or 0.1 , $0.5,1,2$, and $4 \mu \mathrm{g} / \mathrm{ml}$ (apoE-3), and the cells were incubated for an additional $4 \mathrm{~h}$ at $4^{\circ} \mathrm{C}$. The supernatant was collected, and the cells were washed and lysed with $0.1 \mathrm{~N}$ sodium hydroxide. Cell-associated radioactivity was quantitated by TCA precipitation of an aliquot of the lysed cells. Cell protein content was determined, and cell-associated LDL was calculated per microgram of cell protein (39). The competition data were used to determine the apoE liposome concentration required to displace $50 \%$ of bound LDL. The inhibition of LDL binding by normal apoE- 3 was defined as $100 \%$, and the relative inhibition by apoE-1 ( Lys $\left.{ }^{146} \rightarrow \mathrm{Glu}\right)$ and apoE-2 was calculated (40).

The ligands used were prepared as follows: LDL in $10 \mathrm{M}$ glycine ( $\mathrm{pH} 10)$ was iodinated with iodine- $125(1 \mathrm{mCi} / \mathrm{mg} \mathrm{LDL})$ by the iodine monochloride method as modified for lipoproteins (41). Specific activities ranged from 100 to $150 \mathrm{cpm} / \mathrm{ng}$ LDL, containing < 4\% labeled lipid as determined by Folch extraction. ApoE-phospholipid complexes (apoE liposomes) were prepared as described by Havinga et al. (42).

Heparin binding. Heparin-Sepharose CL 6B and Sepharose CL 6B were obtained from Pharmacia LKB Biotechnology Inc. (Piscataway, $\mathrm{NJ}$ ) and prepared as recommended by the manufacturer. Heparin-binding assays were performed under nondenaturing and denaturing conditions.

For binding of radiolabeled apoE under nondenaturing conditions, $4 \mathrm{mg}$ of heparin-Sepharose or $4 \mathrm{mg}$ Sepharose was incubated for $4 \mathrm{~h}$ at $4^{\circ} \mathrm{C}$ in $200 \mu \mathrm{l} 10 \mathrm{mM}$ Tris- $\mathrm{HCl}, \mathrm{pH} 7.5,50 \mathrm{mM} \mathrm{NaCl}$, and $1 \%$ BSA containing radioiodinated apoE liposomes $(1 \mu \mathrm{g}$ protein $/ \mathrm{ml})$. ApoE-1 ( Lys ${ }^{146} \rightarrow \mathrm{Glu}$ ), apoE-2, and apoE-3 were radioiodinated (specific activity: $1,714-1,900 \mathrm{dpm} / \mathrm{ng}$ ) and packed into liposomes as described earlier. After incubation of the gel with the respective apoE, the gel matrix was sedimented by centrifugation at $10,000 \mathrm{~g}$. The radioactivity in $100-\mu \mathrm{l}$ aliquots of the top and bottom fractions was quantitated and the amount of gel-bound ligand was determined by subtracting the radioactivity of the top aliquot from that of the bottom aliquot. Heparin binding was corrected for nonspecific Sepharose binding by subtracting Sepharose gel-bound radioactivity and expressed as nanograms of apoE bound per microgram of heparin. The mass of heparin in heparin-Sepharose was quantitated by uronic acid determination (43).

For binding under denaturing conditions, the assay was modified as follows: the incubation buffer consisted of $5 \mathrm{M}$ urea, $2 \mathrm{mM} \mathrm{NaH}_{2} \mathrm{PO}_{4}$ $\times \mathrm{H}_{2} \mathrm{O} / \mathrm{Na}_{2} \mathrm{HPO}_{4} \times 7 \mathrm{H}_{2} \mathrm{O}, \mathrm{pH} 7.8,50 \mathrm{mM} \mathrm{NaCl}$, and $1 \%$ BSA. Radiolabeled apoE-1 ( Lys $\left.{ }^{146} \rightarrow \mathrm{Glu}\right)$, apoE-2, and apoE-3 $(1 \mu \mathrm{g}$ protein $/ \mathrm{ml})$ were used as ligands.

\section{Results}

Structural analysis. To determine the underlying mutation in apo E-1 $1_{\text {Harrisburg }}$, genomic DNAs from the proband and from a control subject with the phenotype apoE-3/3 were amplified by
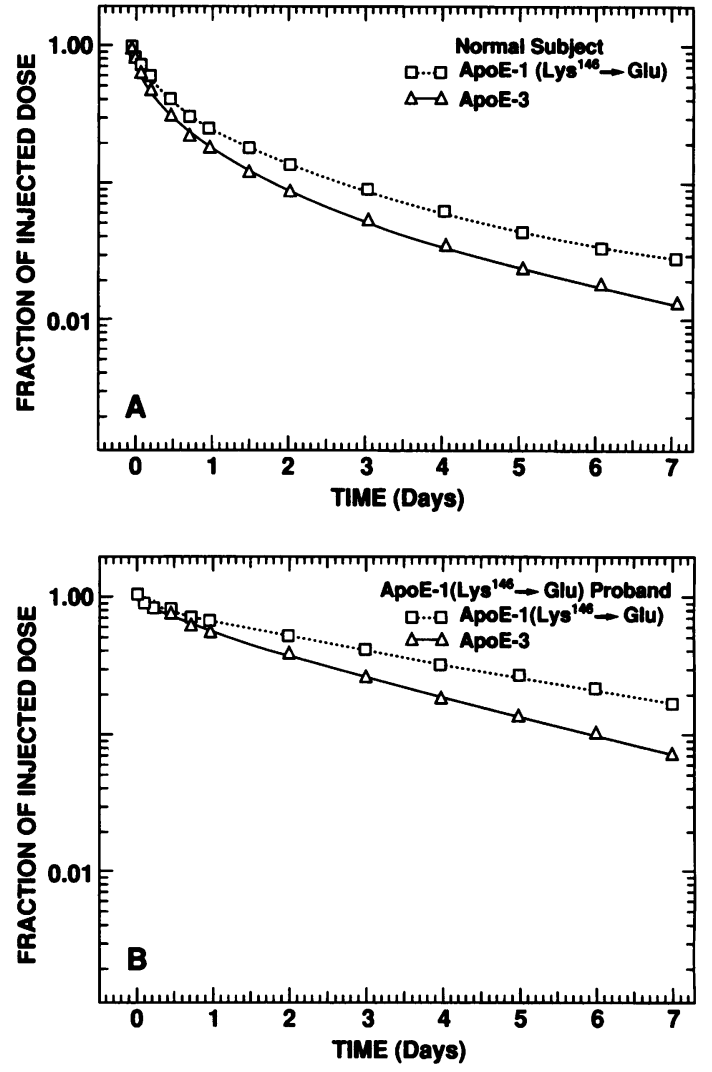

Figure 1. Plasma radioactivity curves of ${ }^{125} \mathrm{I}-\mathrm{apoE}-1$ (Lys ${ }^{146} \rightarrow \mathrm{Glu}$ ) and ${ }^{131} \mathrm{I}$-apoE-3 in a representative normal subject and in the proband from the Harrisburg kindred. After iodination, ${ }^{125} \mathrm{I}-\mathrm{apoE}-1\left(\mathrm{Lys}^{146} \rightarrow \mathrm{Glu}\right)$ and ${ }^{131} \mathrm{I}$-apoE-3 were reassociated with lipoproteins and simultaneously injected into a $(A)$ normolipidemic subject homozygous for apoE-3 and into $(B)$ the proband with an apoE-1 (Lys ${ }^{146} \rightarrow$ Glu $) / E-3$ phenotype.

PCR using apoE-specific primers. Sequence analysis revealed a single base exchange of a $\mathrm{G}$ for an $\mathrm{A}$ at position 254 within exon 4 of the apoE gene, which results in the substitution of lysine (AAG) by glutamic acid (GAG) at amino acid position 146 in the proposed receptor-binding domain of apoE. The other allele was found to be normal, thus establishing that the patient is a heterozygote for the $\Sigma-1\left(\right.$ Lys $^{146} \rightarrow$ Glu $)$ allele.

In vivo kinetic studies. Six normal subjects with an apoE$3 / 3$ phenotype and the proband participated in the in vivo kinetic study. The lipid and lipoprotein profiles of the participants are shown in Table I. Radiolabeled ${ }^{125} \mathrm{I}$-apoE-1 ( Lys $^{146} \rightarrow$ Glu $)$ and ${ }^{131} \mathrm{I}$-apoE-3 were injected simultaneously, and blood samples were obtained at intervals through day 7 . Steady state conditions during the study were demonstrated by multiple determinations of plasma apoE levels (data not shown). Radioactivity was quantitated at each time point, plasma decay curves were plotted, and residence times were calculated using computerassisted curve fitting. The catabolism of apoE-1 (Lys ${ }^{146} \rightarrow$ Glu) and apoE-3 in one of the normal subjects is illustrated in Fig. $1 A$, representative for the six controls studied. ApoE-1(Lys ${ }^{146} \rightarrow$ Glu) was catabolized significantly slower (RT, 0.91 d) than apoE-3 (RT, $0.66 \mathrm{~d})$ in all normal subjects $(P<0.005)$. The proband, in contrast, catabolized both apoE-1 ( Lys $^{146} \rightarrow$ Glu) (RT, $3.76 \mathrm{~d}$ ) and normal apoE-3 (RT, $2.32 \mathrm{~d}$ ) much slower than did the controls (Fig. $1 B$ ). The kinetic parameters of radiolabeled apoE-1 ( Lys $\left.^{146} \rightarrow \mathrm{Glu}\right)$ and apoE-3 are summarized 
Table II. Parameters of Metabolism of ApoE-1 $\left(\right.$ Lys $^{146} \rightarrow$ Glu $)$ and ApoE-3

\begin{tabular}{lcccc}
\hline \multicolumn{1}{c}{ Subject } & $\begin{array}{c}\text { ApoE } \\
\text { isoprotein }\end{array}$ & $\begin{array}{c}\text { ApoE } \\
\text { concentration* }\end{array}$ & RT & $\begin{array}{c}\text { Production } \\
\text { rate }\end{array}$ \\
\hline \multirow{3}{*}{$\begin{array}{l}\text { ApoE-3/3 controls } \\
1\end{array}$} & & $m g / d l$ & days & $m g / k g \times$ days \\
& E-1 & - & 1.10 & - \\
2 & E-3 & 3.6 & 0.72 & 2.23 \\
& E-1 & - & 1.04 & - \\
3 & E-3 & 5.6 & 0.68 & 3.60 \\
& E-1 & - & 0.82 & - \\
4 & E-3 & 4.8 & 0.60 & 3.71 \\
& E-1 & - & 1.00 & - \\
5 & E-3 & 5.6 & 0.68 & 3.91 \\
6 & E-1 & - & 0.82 & - \\
& E-3 & 4.0 & 0.71 & 2.22 \\
Mean \pm SEM & E-1 & - & 0.65 & - \\
apoE-1 & E-3 & 4.1 & 0.56 & 2.88 \\
& E-1 & - & $0.91 \pm 0.17$ & - \\
& E-3 & $4.6 \pm 0.85$ & $0.66 \pm 0.07$ & $3.09 \pm 0.75$ \\
& E-1 & 36.5 & 3.76 & 3.88 \\
& E-3 & 13.5 & 2.32 & 2.32 \\
\hline
\end{tabular}

* Normal apoE concentration, $5.7 \pm 1.4 \mathrm{mg} / \mathrm{dl}$.

in Table II. The mean RT for apo E-3 in the normal subjects was $0.66 \pm 0.07 \mathrm{~d}$, with the production rate at $3.09 \pm 0.75 \mathrm{mg} /$ $\mathrm{kg} \times \mathrm{d}$, which agrees with previous turnover studies of apoE3 (32). In the proband, RTs were greatly prolonged, with 3.76 $\mathrm{d}$ for apo E-1 (Lys ${ }^{146} \rightarrow \mathrm{Glu}$ ) and $2.32 \mathrm{~d}$ for apoE-3. Moreover, the proband's production rate for total apoE was about two times higher than in controls, with $6.2 \mathrm{mg} / \mathrm{kg} \times \mathrm{d}$. The increased apoE levels in the proband were therefore due to both a decreased fractional catabolic rate and an increased production rate.

The lipoprotein distribution of ${ }^{125} \mathrm{I}-\mathrm{apoE}-1$ ( Lys $^{146} \rightarrow \mathrm{Glu}$ ) and ${ }^{131} \mathrm{I}-\mathrm{apoE}-3$, analyzed $10 \mathrm{~min}$ after injection by sequential ultracentrifugation of plasma samples of two normal subjects and of the proband, was very similar, as shown in Table III. However, in contrast to the controls, the majority of apoE$1\left(\right.$ Lys $^{146} \rightarrow$ Glu $)$ and apoE-3 accumulated in the VLDL subfraction of the proband.

Table III. Lipoprotein Distribution of ApoE-1 (Lys ${ }^{146} \rightarrow$ Glu) and ApoE-3

\begin{tabular}{lrrrrrrrr}
\hline & \multicolumn{2}{c}{ Subject 1 } & & \multicolumn{2}{c}{ Subject 2 } & & \multicolumn{2}{c}{ Proband } \\
\cline { 2 - 3 } Lipoprotein & \multicolumn{1}{c}{ E-1 } & \multicolumn{1}{c}{ E-3 } & & \multicolumn{1}{c}{ E-1 } & \multicolumn{1}{c}{ E-3 } & & E-1 & E-3 \\
\hline VLDL & 28.2 & 26.4 & & 39.2 & 38.1 & & 74.2 & 69.6 \\
IDL & 4.5 & 4.0 & & 7.2 & 16.6 & & 3.8 & 5.5 \\
LDL & 10.8 & 10.9 & & 8.1 & 7.9 & & 1.8 & 1.6 \\
HDL & 29.3 & 36.3 & & 21.1 & 24.2 & & 7.2 & 7.7 \\
LPDS & 27.2 & 24.3 & & 25.3 & 23.1 & & 13.0 & 15.5
\end{tabular}

Plasma lipoproteins of two normal subjects ( 1 and 2 ) and the proband were separated by sequential ultracentrifugation of a plasma sample at 10 min after injection of ${ }^{125} \mathrm{I}$-apoE-1 ${ }^{146}$ and ${ }^{131} \mathrm{I}$-apoE-3. Figures given are percentages.

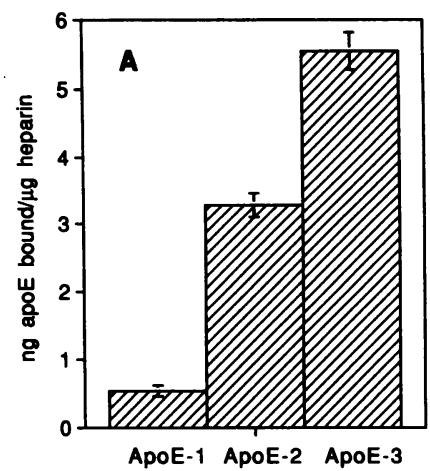

Figure 2. Binding of apoE-1 ( Lys $^{146} \rightarrow$ Glu $)$, apoE-2 ( $\operatorname{Arg}^{158} \rightarrow$ Cys $)$, and apoE-3 to heparin under $(A)$ nondenaturing and $(B)$ denaturing conditions. For binding under nondenaturing conditions, 1 $\mu \mathrm{g} / \mathrm{ml}$ radiolabeled apoE liposomes (apoE-1 ( Lys ${ }^{146} \rightarrow$ Glu ), apoE-2, or apoE-3) were incubated with $4 \mathrm{mg}$ heparin-Sepharose for $4 \mathrm{~h}$ at $4^{\circ} \mathrm{C}$ in $200 \mu \mathrm{l} 10$ $\mathrm{mM}$ Tris- $\mathrm{HCl}, \mathrm{pH} 7.5,50 \mathrm{mM}$ $\mathrm{NaCl}$, and $1 \%$ BSA. After incubation, the gel matrix was recovered by centrifugation, and the matrix-bound radioactivity was quantitated. Nonspecific binding was determined by parallel incubations with Sepharose free of heparin. Under denaturing conditions, $1 \mu \mathrm{g} / \mathrm{ml}$ of radiolabeled apoE was incubated in $5 \mathrm{M}$ urea, $2 \mathrm{mM} \mathrm{NaH}_{2} \mathrm{PO}_{4} \times \mathrm{H}_{2} \mathrm{O} /$ $\mathrm{Na}_{2} \mathrm{HPO}_{4} \times 7 \mathrm{H}_{2} \mathrm{O}, \mathrm{pH} 7.8,50$ $\mathrm{mM} \mathrm{NaCl}$, and $1 \%$ BSA. Values represent the mean \pm SEM of three independent experiments.

Fibroblast binding. To assess the LDL receptor affinity of apoE-1 ( Lys ${ }^{146} \rightarrow$ Glu $)$ as compared with apoE-2 and apoE-3, the ability of the different apoE isoproteins to displace LDL from LDL receptors on normal human fibroblasts was determined. ApoE liposomes were used for these in vitro competition assays to exclude apoB-LDL receptor interactions. Normal human fibroblasts were incubated with $2.5 \mu \mathrm{g} / \mathrm{ml} \mathrm{LDL}$ and increasing concentrations of liposomes containing either apoE-1 (Lys ${ }^{146} \rightarrow$ Glu), apoE-2, or apoE-3. The apoE liposome concentration required to displace $50 \%$ LDL $\left(\mathrm{IC}_{50}\right)$ was calculated, and the receptor affinities of apoE-1 ( Lys ${ }^{146} \rightarrow$ Glu ) and apoE-2 were expressed relative to normal binding of apoE-3. Binding of apoE3 was defined as $100 \%$. Both apoE-1 (Lys ${ }^{146} \rightarrow$ Glu $)$ and apoE2 were comparably defective in their ability to displace LDL from receptors on normal human fibroblasts (apoE-1 ( Lys $^{146} \rightarrow$ Glu ): $7.7 \pm 0.8 \%$; apoE-2: $8.5 \pm 1.0 \%$, Table IV).

Heparin binding. To investigate further the interaction of apoE-1 ( Lys $^{146} \rightarrow$ Glu $)$ and apoE-2 ( Arg $^{158} \rightarrow$ Cys $)$ with polyanionic binding sites similar to the LDL (apoB, apoE) receptor, heparin was used as a model for negatively charged cell surface proteoglycans. Under nondenaturing conditions, the amount of apoE-1 (Lys ${ }^{146} \rightarrow$ Glu $)$ and apoE-2 bound to heparin-Sepharose was decreased to $\sim 10$ and $60 \%$, respectively, compared with the amount of apoE-3 bound (Fig. $2 A$ ). Denaturation of the apoEs with $5 \mathrm{M}$ urea restored the ability of apoE-2 to bind to heparin-Sepharose, while apoE-1 ( Lys ${ }^{146} \rightarrow$ Glu $)$ remained defective (Fig. $2 B$ ).

\section{Discussion}

We have previously described a kindred in which heterozygosity for an apoE mutant, apoE-1 ( Lys $^{146} \rightarrow \mathrm{Glu}$ ), is dominantly associated with the expression of type III HLP (23). In the present study, we investigated this mutant apoE by sequence 
Table IV. LDL Receptor Binding of ApoE Liposomes

\begin{tabular}{lcc}
\hline \multicolumn{1}{c}{ ApoE isoprotein } & $\mathrm{IC}_{50}(\mathrm{ng} / \mathrm{ml}) \pm$ SEM $^{*}$ & Percentage of activity \\
\hline ApoE-1(Lys ${ }^{146} \rightarrow$ Glu $)$ & $887 \pm 87$ & $7.7 \pm 0.7$ \\
ApoE-2 & $825 \pm 96$ & $8.4 \pm 1.0$ \\
ApoE-3 & $69 \pm 7$ & $100 \pm 11$ \\
\hline
\end{tabular}

Competition data were obtained by incubating normal human fibroblasts with $2.5 \mu \mathrm{g} / \mathrm{ml}^{125} \mathrm{I}$ LDL with increasing concentrations of apoE liposomes for $4 \mathrm{~h}$ at $4^{\circ} \mathrm{C}$. * $\mathrm{IC}_{50}$, concentration of apoE required to displace $50 \%{ }^{125} \mathrm{I}$ LDL.

analysis, in vivo kinetic studies, and in vitro binding studies. Analysis of the proband's apoE gene revealed a single base exchange of a $G$ for an $A$ at position 254 within exon 4, resulting in a lysine (AAG) to glutamic acid (GAG) substitution at amino acid position 146 in the proposed receptor binding domain of the apoE molecule. The other allele encoded the normal isoprotein apoE-3. These results agree with previously performed amino acid analyses of the mutant apoE (24).

To assess the metabolic effect of this mutation, an in vivo kinetic study was performed by simultaneously injecting ${ }^{125} \mathrm{I}$ apoE-1 ( Lys ${ }^{146} \rightarrow$ Glu $)$ and ${ }^{131} \mathrm{I}$-apoE-3 into the proband and into six normal volunteers (Table II). In the control subjects, apoE1 (Lys ${ }^{146} \rightarrow$ Glu ) was catabolized significantly slower than was apoE-3; in the proband, both residence times were markedly prolonged. These results demonstrate that apoE- 1 ( Lys ${ }^{146} \rightarrow \mathrm{Glu}$ ) not only has an impaired in vivo metabolism but also interferes with the catabolism of apoE-3, thus leading to a greatly prolonged residence time of the normal $\mathrm{E}$ isoprotein in the patient. In addition, there was an approximately twofold increase in the production rate of apoE-1 ( Lys $^{146} \rightarrow \mathrm{Glu}$ ) compared with its normal counterpart (Table II). In the patient, therefore, the $\sim 10$ times elevated plasma apoE levels were due to both a decreased fractional catabolic rate and an increase in apoE production. Previously performed kinetic studies of apoE-2$\left(\right.$ Arg ${ }^{158} \rightarrow$ Cys) also showed a decreased fractional rate for apoE-2 (9) as an experimental correlate of impaired function. However, the defect of apoE-1 appears more severe, because it results in dominant manifestation of disease as opposed to the recessive mode observed for apoE-2. One possible explanation is that the LDL receptor-binding affinity of apoE-1 ( Lys ${ }^{146} \rightarrow$ Glu ) is lower than that of apoE-2. However, this is not the case. ApoE-2 and apoE-1 ( Lys ${ }^{146} \rightarrow$ Glu $)$ were both shown to possess $8 \%$ of normal receptor-binding activity in an in vitro competition assay using apoE liposomes. Thus, differential binding of apoE-1 ${ }^{146}$ and apoE-2 to the LDL receptor binding does not discriminate between dominant and variable manifestation of type III HLP. This conclusion is supported by the data recently published by Moriyama et al. (25). His group reported that ApoE-1 (Lys ${ }^{146} \rightarrow$ Glu), which was isolated from a Japanese proband and complexed with dimyristoylphosphatidylcholine, bound to the LDL receptor with less than $10 \%$ of the affinity of normal apoE3 . With the exception of apoE-2 ( $\operatorname{Arg}^{158} \rightarrow$ Cys $)$, which has a receptor-binding activity as low as $1 \%(10)$, apoE-1 (Lys ${ }^{146} \rightarrow$ $\mathrm{Glu})$ is the most binding-defective naturally occurring apoE mutant described. In comparison, the binding activities of apoE3 (Cys ${ }^{112} \rightarrow$ Arg, Arg ${ }^{142} \rightarrow$ Cys), apoE-3 (duplication of residues $120-126$ ), and apoE-2 (Lys ${ }^{146} \rightarrow$ Gln $)$ were $\sim 20,25$, and $35-$ $40 \%$, respectively, compared with apoE-3 $(13,18,44)$. The latter mutant demonstrates the importance not only of the position of the mutated residue, but also of the charge of the newly introduced amino acid on LDL receptor-binding activity. The substitution of the basic residue 146 , lysine, by the polar amino acid glutamine in apoE-2(Lys ${ }^{146} \rightarrow$ Gln $)$ and by the negatively charged glutamic acid in apoE-1 (Lys ${ }^{146} \rightarrow$ Glu $)$ occurs in the center of the proposed receptor-binding domain of apoE, which contains six positively charged amino acids. A three dimensional crystallographic analysis of this domain revealed that residue 146, lysine, is directed toward the aqueous phase and is not involved in forming salt bridges within the apoE molecule, thus being available for intermolecular interactions with acidic residues of the LDL receptor (45). A substitution at this position is expected to adversely affect binding by directly altering the ionic interactions between ligand and receptor.

Based on the fact that several apoEs are present on a single lipoprotein particle, multiple interactions between apoE molecules and its receptors may be necessary (oligomeric ligandreceptor interaction). This concept is supported by data from Nykjaer et al. (46), who showed that it is the dimeric form of lipoprotein lipase that mediates binding of $\beta$-VLDL to LRP. Thus the binding-defective apoE mutant would prevent the formation of the required number of ionic interactions of the exposed apoE on the particle surface with its receptor, even in the presence of normal apoE-3 (Fig. 3). This would explain why the proband from the Harrisburg kindred catabolized both apoE-1 ( Lys $^{146} \rightarrow$ Glu $)$ and apoE-3 much slower than did the normal controls, resulting in the accumulation in plasma of particles containing both mutant and normal apoE. The especially slow removal from circulation of the mutant apoE and its twofold increased production rate and secretion, compared with the normal counterpart, explains the predominance in plasma of apoE-1 ( Lys $^{146} \rightarrow$ Glu $)$ over normal apoE-3 at a ratio of approximately 3:1 and the increased pool size of lipoproteins with low receptor affinity. In addition, apoE-1 ( Lys $^{146} \rightarrow$ Glu) may associate preferentially with chylomicrons and VLDL. The enrichment of VLDL particles with binding-defective apoE3 (Cys ${ }^{112} \rightarrow$ Arg,Arg ${ }^{142} \rightarrow$ Cys) and apoE-3 (duplication of residues $120-126$ ) has already been proposed to promote the expression of type III HLP $(44,47)$. Our data, however, indicate that apoE-1 ( Lys ${ }^{146} \rightarrow$ Glu $)$ and apoE-3 distribute equally well to all lipoprotein classes in both normal subjects and in the proband (Table III). The predominant association of both apoE with the VLDL subfraction of the proband is explained by the high levels of VLDL accumulating in the patient's plasma due to the delayed catabolism of apoE-1 ( Lys $^{146} \rightarrow$ Glu $)$. Since VLDLs readily acquire added apoE, the enrichment of these particles with apoE appears to be a symptom of type III HLP rather than a consequence of an increased affinity of the mutant apoE for triglyceride-rich lipoproteins.

To investigate further LDL receptor-independent ionic interactions of apoE with cell membranes, we analyzed the binding of apoE-3, apoE-2 ( $\mathrm{Arg}^{158} \rightarrow \mathrm{Cys}$ ), and apoE-1 ( Lys ${ }^{146} \rightarrow \mathrm{Glu}$ ) to heparin as a model for cell surface proteoglycans. There are two heparin-binding sites in the apoE molecule $(48,49)$, and one is contained within the region of the molecule implicated in LDL receptor binding (amino acids 135-150). The replacement of residue 142, arginine, by cysteine in apoE-3 (Cys ${ }^{112} \rightarrow$ $\mathrm{Arg}, \mathrm{Arg}^{142} \rightarrow$ Cys) has already been shown to result in a weaker affinity for heparin as measured by salt gradient elution (44). We could show that the binding of apoE- $1\left(\right.$ Lys $^{146} \rightarrow$ Glu $)$ was reduced to $10 \%$ of apoE-3, whereas the affinity of apoE- 2 was 


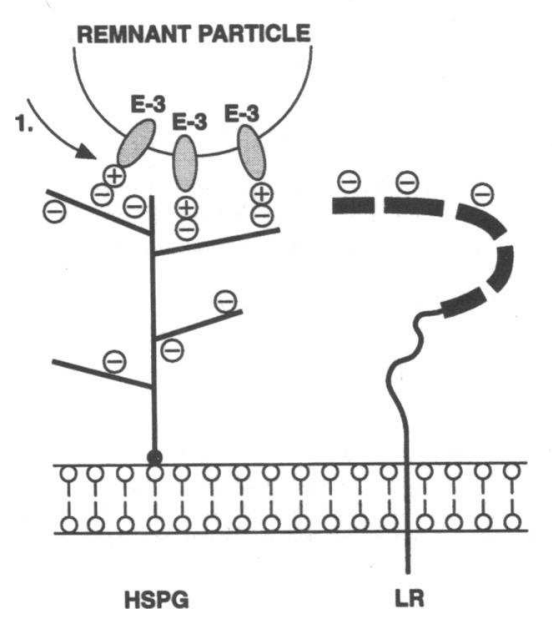

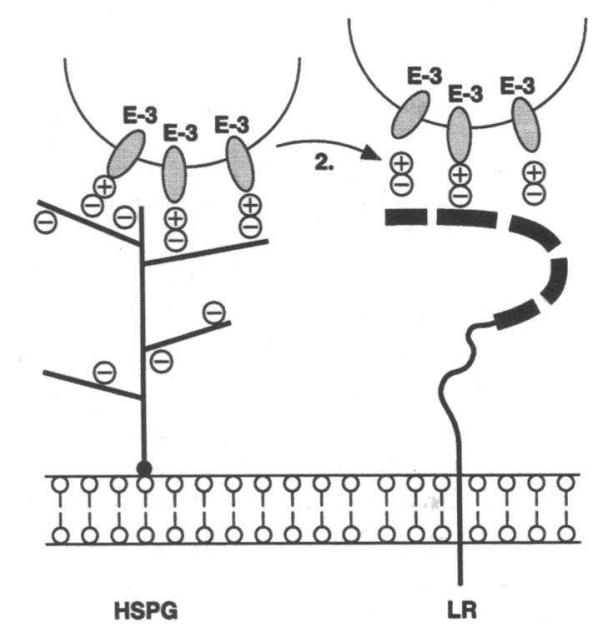

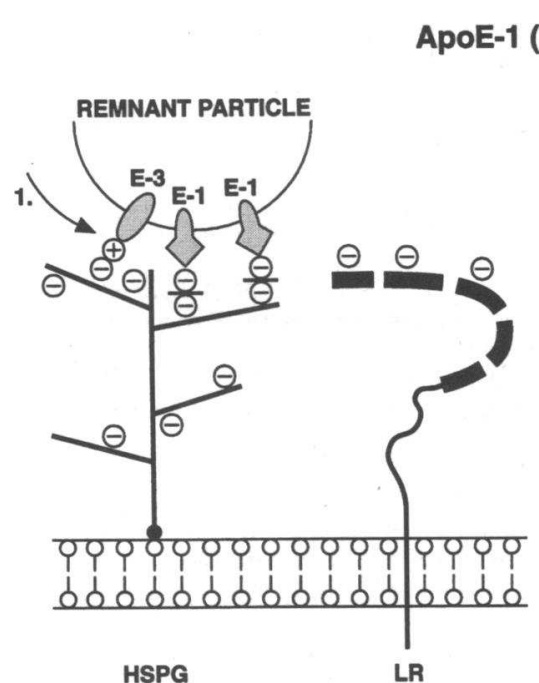

ApoE-1 (Lys ${ }^{146} \rightarrow$ Glu)

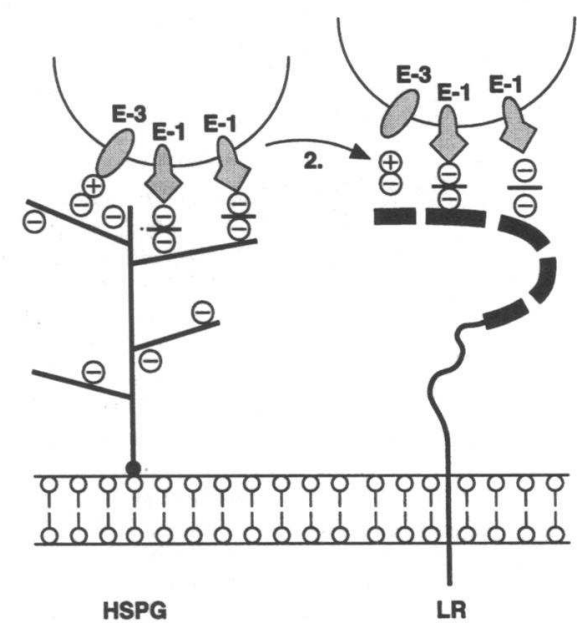

Figure 3. Schematic model of the proposed oligomeric ligand-receptor interactions prevented by apoE-1 ( Lys ${ }^{146} \rightarrow$ Glu $)$. (Top) Normal binding of remnant particles to cells may involve two steps. First apoE mediates binding of the particle to heparan sulfate proteoglycans ( $H S P G)$ by an interaction of the positive residues in the receptor-binding region of apoE with negative charges in the polysulfated heparan side chains. This sequestration of the particle on the cell surface may facilitate step 2: the binding to lipoprotein receptors $(L R)$ before receptor-mediated uptake $(58,62)$. Again multiple interactions with negatively charged residues in the ligandbinding repeats $(\square)$ of the lipoprotein receptor may be required. (Bottom) The presence of apoE-1 ( Lys ${ }^{146} \rightarrow$ Glu ) may prevent the formation of a sufficient number of ionic interactions, even in the heterozygous state. The charge of residue 146 may play a crucial role in this process and is indicated as plus $\left(\mathrm{Lys}^{146}\right)$ or minus $\left(\mathrm{Glu}^{146}\right)$ sign. The missing of oligomeric ligand-receptor interactions could represent one important factor in the dominant expression of type III HLP.
$59 \%$ of normal. Unfolding of the protein under denaturing conditions resulted in a normalization of the heparin binding of apoE-2, while apoE-1 (Lys ${ }^{146} \rightarrow$ Glu $)$ remained defective. Thus, it is not a change in the three-dimensional conformation of apoE-1 (Lys ${ }^{146} \rightarrow$ Glu $)$ but rather the charge shift in the linear amino acid sequence that seems responsible for its low affinity to heparin.

This finding agrees with previously performed chemical modification experiments demonstrating the importance of positively charged arginine and lysine residues in the binding of apoB and apoE to heparin (50). It is interesting that the opposite appears to true for apoE-2( $\left.\operatorname{Arg}^{158} \rightarrow \mathrm{Cys}\right)$. This result corroborates earlier studies which demonstrated that the severe binding defect of apoE-2 is due mainly to conformational changes $(44,51)$.

The physiological relevance of the in vivo binding of apoE to heparin is unknown. However, evidence from in vitro experiments indicates that cell surface proteoglycans, including heparin, could have a receptor-like function for both apoE- $(52,53)$ and apoB- (54) containing lipoproteins. To analogize to the fibroblast growth factor family (55-57) these lipoproteins could interact with heparin or heparin-like heparan sulfate pro- teoglycans on the cell surface and, in a second step, be presented to LDL or apoE (remnant) receptors, which in turn mediate the cellular uptake of these particles $(53,58)$. In addition, binding of apoE to heparan sulfate proteoglycans could bring triglyceride- and apoE-rich particles into close spatial relationship with lipolytic enzymes (hepatic lipase, reference 59, lipoprotein lipase: reference 60 ), thereby enhancing hydrolysis of triglycerides as well as cellular binding and uptake of these lipoproteins. Nascent apoE may also become bound to proteoglycans inside the cell and then be transported to the membrane, where they serve as an apoE reservoir for the uptake of lipoproteins (61, 62). Defective proteoglycan binding of apoE may thus result in ineffective retardation of apoE on the cell surface with an apparently higher rate of secretion. In our kinetic study, the production rate of the mutant apoE-1 was indeed increased twofold, compared with apoE-3, which would be in accordance with the proposed mechanism. However, direct measurements of transcriptional or secretional levels could not be done because a liver biopsy would have been required.

At least two other apoE mutants associated with dominant expression of type III HLP, apoE-2( Lys $^{146} \rightarrow$ Gln $)$ and apoE$4\left(\right.$ Glu $^{13} \rightarrow$ Lys, Arg ${ }^{145} \rightarrow$ Cys $)$, are also impaired in their binding 
to heparin. Ji et al. (63) recently showed that defective binding of apoE variants to heparan sulfate proteoglycan paralleled defective remnant binding, mediated by the respective apoE variant in vitro. It was concluded from this study that defective binding of apoE to proteoglycans may correlate with the expression of type III HLP. Following these data, together with the presented results of our in vivo kinetic studies, heparin binding, in addition to plasma apoE levels (22), may be used to differentiate between recessive and dominant apoE mutants.

In conclusion, in vitro binding assays and in vivo turnover studies demonstrate that the dominant expression of type III HLP associated with apoE-1 (Lys $\left.{ }^{146} \rightarrow \mathrm{Glu}\right)$ is due to $(a)$ an overexpression of the mutated allele, $(b)$ an impaired binding of the mutant apoE to LDL receptors, and $(c)$ a slow removal from the plasma compartment of particles containing both mutant and normal apoE. Defective binding of apoE-1 (Lys ${ }^{146} \rightarrow$ Glu) to heparin or heparin-like proteoglycans may play a significant role in the manifestation of this disease. Our combined data indicate that dominantly transmitted type III HLP is a multifactorial disorder of apoE metabolism.

\section{Acknowledgments}

We thank the dietary and nursing staff of the National Institutes of Health Clinical Center and the normal volunteers who participated in these studies.

Dr. Mann and Dr. Lohse were supported by the Deutsche Forschungsgemeinschaft.

\section{References}

1. Mahley, R. W. 1988. Apolipoprotein E: cholesterol transport protein with expanding role in cell biology. Science (Wash. DC). 240:622-630.

2. Brown, M. S., J. Herz, R. C. Kowal, and J. L. Goldstein. 1991. The lowdensity lipoprotein receptor-related protein: double agent or decoy? Curr. Opin. Lipidol. 2:65-72.

3. Utermann, G., M. Hees, and A. Steinmetz. 1977. Polymorphism of apolipoprotein $\mathrm{E}$ and occurrence of dysbetalipoproteinemia in man. Nature (Lond.). 269:604-607.

4. Zannis, V. I., and J. L. Breslow. 1981. Human very low density lipoprotein apolipoprotein $\mathrm{E}$ isoprotein polymorphism is explained by genetic variation and posttranslational modification. Biochemistry. 20:1033-1041.

5. Weisgraber, K. H., S. C. Rall, Jr., and R. W. Mahley. 1981. Human E apoprotein heterogeneity. Cysteine-arginine interchanges in the amino acid sequence of the apo-E isoforms. J. Biol. Chem. 256:9077-9083.

6. Havel, R. J. 1982. Familial dysbetalipoproteinemia. New aspects of pathogenesis and diagnosis. Med. Clin. N. Am. 66:441-454.

7. Brewer, H. B., Jr., L. A. Zech, R. E. Gregg, D. Schwartz, and E. J. Schaefer. 1983. Type III hyperlipoproteinemia: diagnosis, molecular defects, pathology, and treatment. Ann. Intern. Med. 98:623-640.

8. Mahley, R. W., and S. C. Rall, Jr. 1989. Type III hyperlipoproteinemia (dysbetalipoproteinemia): the role of apolipoprotein $\mathrm{E}$ in normal and abnormal lipoprotein metabolism. In The Metabolic Basis of Inherited Disease, 6th ed. C. R. Scriver, A. L. Beaudet, W. S. Sly, and D. Valle, editors. McGraw-Hill, New York. 1195-1213.

9. Gregg, R. E., L. A. Zech, E. J. Schaefer, and H. B. Brewer, Jr. 1981. Type III hyperlipoproteinemia: defective metabolism of an abnormal apolipoprotein $\mathrm{E}$. Science (Wash. DC). 211:584-586.

10. Weisgraber, K. H., T. L. Innerarity, and R. W. Mahley. 1982. Abnormal lipoprotein-receptor-binding activity of the human $\mathrm{E}$ apoprotein due to cysteinearginine interchange at a single site. J. Biol. Chem. 257:2518-2521.

11. Utermann, G. 1985. Genetic polymorphism of apolipoprotein E-impact on plasma lipoprotein metabolism. In Diabetes, Obesity and Hyperlipidemias III. G. Crepaldi, A. Tiengo, and G. Baggio, editors. Excerpta Medica, Amsterdam. $1-28$.

12. Davignon, J., R. E. Gregg, and C. F. Sing. 1988. Apolipoprotein E polymorphism and atherosclerosis. Arteriosclerosis. 8:1-21.

13. Rall, S. C., Jr., K. H. Weisgraber, T. L. Innerarity, T. P. Bersot, R. W. Mahley, and C. B. Blum. 1983. Identification of a new structural variant of human apolipoprotein E, E-2 (Lys ${ }^{146} \rightarrow$ GIn $)$, in a type III hyperlipoproteinemic subject with the E3/2 phenotype. J. Clin. Invest. 72:1288-1297.
14. Smit, M., P. de Knijff, E. van der Kooij-Meijs, C. Groenendijk, A. M. J. M. van den Maagdenberg, J. A. Gevers-Leuven, A. F. H. Stalenhoef, P. M. J. Stuyt, R. R. Frants, and L. M. Havekes. 1990. Genetic heterogeneity in familial dysbetalipoproteinemia. The E2 (lys ${ }^{146} \rightarrow$ gln $)$ variant results in a dominant mode of inheritance. J. Lipid Res. 31:45-53.

15. Havel, R. J., L. Kotite, J. P. Kane, P. Tun, and T. Bersot. 1983. Atypical familial dysbetalipoproteinemia associated with apolipoprotein phenotype E3/3. J. Clin. Invest. 72:379-387.

16. Rall, S. C., Jr., Y. M. Newhouse, H. R. G. Clarke, K. H. Weisgraber, B. J. McCarthy, R. W. Mahley, and T. P. Bersot. 1989. Type III hyperlipoproteinemia associated with apolipoprotein $E$ phenotype E3/3. Structure and genetics of an apolipoprotein E3 variant. J. Clin. Invest. 83:1095-1101.

17. Havekes, L., E. de Wit, J. Gevers Leuven, E. Klasen, G. Utermann, W. Weber, and U. Beisiegel. 1986. Apolipoprotein E3-Leiden. A new variant of human apolipoprotein E associated with familial type III hyperlipoproteinemia. Hum. Genet. 73:157-163.

18. Wardell, M. R., K. H. Weisgraber, L. M. Havekes, and S. C. Rall, Jr. 1989. Apolipoprotein E3-Leiden contains a seven-amino acid insertion that is a tandem repeat of residues 121-127. J. Biol. Chem. 264:21205-21210.

19. van den Maagdenberg, A. M. J. M., P. de Knijff, A. F. H. Stalenhoef, J. A. Gevers Leuven, L. M. Havekes, and R. R. Frants. 1989. Apolipoprotein E*3-Leiden allele results from a partial gene duplication in exon 4. Biochem. Biophys. Res. Comm. 165:851-857.

20. de Knijff, P., A. M. J. M. van den Maagdenberg, A. F. H. Stalenhoef, J.A. Gevers Leuven, P. N. M. Demacker, L. P. Kuyt, R. R. Frants, and L. M. Havekes. 1991. Familial dysbetalipoproteinemia associated with apolipoprotein E3-Leiden in an extended multigeneration pedigree. J. Clin. Invest. 88:643-655.

21. Lohse, P., W. A. Mann, E. A. Stein, and H. B. Brewer, Jr. 1991. Apolipoprotein E-4 philedelphia (Glu 13 $\rightarrow$ Lys,Arg145 $\rightarrow$ Cys). Homozygosity for two rare point mutations in the apolipoprotein $\mathrm{E}$ gene combined with severe type III hyperlipoproteinemia. J. Biol. Chem. 266:10479-10484.

22. Lohse, P., D. J. Rader, and H. B. Brewer, Jr. 1992. Heterozygosity for

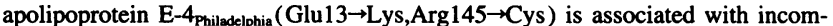
plete dominant expression of type III hyperlipoproteinemia. J. Biol. Chem. 267:13642-13646.

23. Mann, W. A., R. E. Gregg, D. L. Sprecher, and H. B. Brewer, Jr. 1989. Apolipoprotein E-1 $1_{\text {Harrisburg }}$ : a new variant of apolipoprotein $\mathrm{E}$ dominantly associated with type III hyperlipoproteinemia. Biochim. Biophys. Acta. 1005:239-244.

24. Mann, A. W., R. E. Gregg, R. Ronan, T. Fairwell, J. M. Hoeg, and H. B. Brewer, Jr. 1989. Apolipoprotein E-1 Harrisburg, a mutation in the receptor binding domain, that is dominant for dysbetalipoproteinemia results in defective ligand-receptor interactions. Clin. Res. 37:520A. (Abstr.)

25. Moriyama, K., J. Sasaki, A. Matsunaga, F. Arakawa, Y. Takada, K. Araki, S. Kaneko, and K. Arakawa. 1992. Apolipoprotein E-1 Lys-146 $\rightarrow$ Glu with type III hyperlipoproteinemia. Biochem. Biophys. Acta. 1128:58-64.

26. Messing, J. 1983. New M13 vectors for cloning. Methods Enzymol. 101:20-78.

27. Sanger, F., S. Nicklen, and A. R. Coulson. 1977. DNA sequencing with chain-terminating inhibitors. Proc. Natl. Acad. Sci. USA. 74:5463-5467.

28. Havel, R. J., H. A. Eder, and J. H. Bragdon. 1955. The distribution and chemical composition of ultracentrifugally separated lipoproteins in human serum. J. Clin. Invest. 34:1345-1353.

29. Radding, C. M., and D. Steinberg. 1960. Studies on the synthesis and secretion of serum lipoproteins by rat liver slices. J. Clin. Invest. 39:1560-1569.

30. Zannis, V. I. 1986. Genetic polymorphism in human apolipoprotein E. Methods Enzymol. 128:823-851.

31. McFarlane, A. S. 1958. Efficient trace labeling of proteins with iodine. Nature (Lond.). 182:53-54.

32. Gregg, R. E., L. A. Zech, E. J. Schaefer, and H. B. Brewer, Jr. 1984. Apolipoprotein $\mathrm{E}$ metabolism in normolipoproteinemic human subjects. J. Lipid Res. 25:1167-1176.

33. Ghiselli, G., E. J. Schaefer, L. A. Zech, R. E. Gregg, and H. B. Brewer, Jr. 1982. Increased prevalence of apolipoprotein E4 in type V hyperlipoproteinemia. J. Clin. Invest. 70:474-477.

34. Gregg, R. E., D. Wilson, E. Rubalcaba, R. Ronan, and H. B. Brewer, Jr. 1983. Immunoquantitation of apolipoprotein E. In Proceedings of the Workshop on Apolipoprotein Quantification. K. Lippel, editor. National Institutes of Health Publication 83-1266, Bethesda, MD. 383-401.

35. Warnick, G. R., J. Benderson, J. J. Albers, E. E. Baillie, B. Sexton, E. J. Schaefer, D. Carlson, M. Hill, H. B. Brewer, Jr., D. A. Wiebe, J. Hazlehurst, and G. R. Cooper. 1982. Dextran sulfate- $\mathrm{Mg}^{2+}$ precipitation procedure for quantitation of high density-lipoprotein cholesterol. Clin. Chem. 28:1379-1388.

36. Manual of Laboratory Operations, Lipid Research Clinics Program. 1974. U.S. Department of Health, Education, and Welfare Publication No. 75-628. National Heart, Lung, and Blood Institute, Bethesda, MD.

37. Berman, M., and M. R. Weiss. 1978. SAAM Manual. U.S. Department of Health, Education, and Welfare Publication No. 78-180. National Institutes of Health, Bethesda, MD.

38. Hoeg, J. M., S. J. Demosky, Jr., E. J. Schaefer, T. E. Starzl, and H. B. Brewer, Jr. 1984. Characterization of hepatic low density lipoprotein binding and 
cholesterol metabolism in normal and homozygous familial hypercholesterolemic subjects. J. Clin. Invest. 73:429-436.

39. Goldstein, J. L., and M. S. Brown. 1974. Binding and degradation of low density lipoproteins by cultured human fibroblasts. Comparison of cells from a normal subject and from a patient with homozygous familial hypercholesterolemia. J. Biol. Chem. 249:5153-5162.

40. Innerarity, T. L., R. E. Pitas, and R. W. Mahley. 1986. Lipoproteinreceptor interactions. Methods Enzymol. 129:542-565.

41. Bilheimer, D. W., S. Eisenberg, and R. I. Levy. 1972. The metabolism of very low density lipoprotein proteins. I. Preliminary in vitro and in vivo observations. Biochim. Biophys. Acta. 260:212-221.

42. Havinga, J. R., P. Lohse, and U. Beisiegel. 1987. Immunoblotting and ligand blotting of the low-density lipoprotein receptor of human liver, HepG2 cells and HeLa cells. FEBS (Fed. Eur. Biochem. Soc.) Lett. 216:275-280.

43. Bitter, T., and H. M. Muir. 1962. A modified uronic acid carbazole reaction. Anal. Biochem. 4:330-334.

44. Horie, Y., S. Fazio, J. R. Westerlund, K. H. Weisgraber, and S. C. Rall, Jr. 1992. The functional characteristics of a human apolipoprotein $\mathrm{E}$ variant (cysteine at residue 142) may explain its association with dominant expression of type III hyperlipoproteinemia. J. Biol. Chem. 267:1962-1968.

45. Wilson, C., M. R. Wardell, K. H. Weisgraber, R. W. Mahley, and D. A. Agard. 1991. Three-dimensional structure of the LDL receptor-binding domain of human apolipoprotein E. Science (Wash. DC). 252:1817-1822.

46. Nykjaer, A., G. Bengtsson-Olivecrona, A. Lookene, S. K. Moestrup, C. M. Petersen, W. Weber, U. Beisiegel, and J. Gliemann. 1993. Purified alpha2-macroglobulin receptor/LDL receptor related protein binds lipoprotein lipase and lipoproteins associated with the lipase. J. Biol. Chem. 268:15048-15055.

47. Fazio, S., Y. Horie, K. H. Weisgraber, L. M. Havekes, and S. C. Rall, Jr. 1993. Preferential association of apolipoprotein $E_{\text {Leiden }}$ with very low density lipoproteins of human plasma. J. Lipid Res. 34:447-453.

48. Cardin, A. D., N. Hirose, D. T. Blankenship, R. L. Jackson, and J. A. K. Harmony. 1986. Binding of a high reactive heparin to human apolipoprotein E: identification of two heparin-binding domains. Biochem. Biophys. Res. Comm 134:783-789.

49. Weisgraber, K. H., S. C. Rall, Jr., R. W. Mahley, R. W. Milne, Y. L. Marcel, and J. T. Sparrow. 1986. Human apolipoprotein E. Determination of the heparin binding sites of apolipoprotein E3. J. Biol. Chem. 261:2068-2076.

50. Mahley, R. W., K. H. Weisgraber, and T. L. Innerarity. 1979. Interaction of plasma lipoproteins containing apolipoproteins $\mathrm{B}$ and $\mathrm{E}$ with heparin and cel surface receptors. Biochim. Biophys. Acta. 575:81-89.

51. Innerarity, T. L. K. H. Weisgraber, K. S. Arnold, S. C. Rall, Jr., and R. W. Mahley. 1984. Normalization of receptor binding of apolipoprotein E2.
Evidence for modulation of the binding site conformation. J. Biol. Chem. 259:7261-7267.

52. Oswald, B., F. Shelburne, B. Landis, A. Linker, and S. Quarfordt. 1986. The relevance of glycosaminoglycan sulfates to apoE induced lipid uptake by hepatocyte monolayers. Biochem. Biophys. Res. Comm. 141:158-164.

53. Ji, Z.-S., W. J. Brecht, R. D. Miranda, M. M. Hussain, T. L. Innerarity, and R. W. Mahley. 1993. Role of heparan sulfate proteoglycans in the binding and uptake of apolipoprotein E-enriched remnant lipoproteins by cultured cells. J. Biol. Chem. 268:10160-10167.

54. Williams, K. J., G. M. Fless, K. A. Petrie, M. L. Snyder, R. W. Brocia and T. L. Swenson. 1992. Mechanisms by which lipoprotein lipase alters cellular metabolism of lipoprotein (a), low density lipoprotein, and nascent lipoproteins. Roles for low density lipoprotein receptors and heparan sulfate proteoglycans. $J$. Biol. Chem. 267:13284-13292.

55. Sakaguchi, K., M. Yanagishita, Y. Takeuchi, and G. D. Aurbach. 1991. Identification of heparin sulfate proteoglycan as a high affinity receptor for acidic fibroblast growth factor (aFGF) in a parathyroid cell line. J. Biol. Chem. 266:7270-7278.

56. Yayon, A., M. Klagsbrun, J. D. Esko, P. Leder, and D. M. Ornitz. 1991. Cell surface, heparin-like molecules are required for binding of basic fibroblast growth factor to its high affinity receptor. Cell. 64:841-848.

57. Rapraeger, A. C., A. Kru f ka, and B. B. Olwin. 1991. Requirement of heparan sulfate for bFGF-mediated fibroblast growth and myoblast differentiation. Science (Wash. DC). 252:1705-1708.

58. Beisiegel, U., A. Krapp, W. Weber, and G. Olivecrona. 1994. The role of alpha2M Receptor/LRP in chylomicron remnant metabolism. Ann. NY Acad. Sci. 737:53-69.

59. Shafi, S., S. E. Brady, A. Bensadoun, and R. J. Havel. 1994. Role of hepatic lipase in the uptake and processing of chylomicron remnants in rat liver. J. Lipid Res. 35:709-720.

60. Mulder, M., P. Lombardi, H. Jansen, T. J. C. van Berkel, R. R. Frants, and L. M. Havekes. 1993. Low density lipoprotein receptor internalizes low density and very low density lipoproteins that are bound to heparan sulfate proteoglycans via lipoprotein lipase. J. Biol. Chem. 268:9369-9375.

61. Lilly-Stauderman, M., T. L. Brown, A. Balasubramaniam, and J. A. K. Harmony. 1993. Heparin releases newly synthesized cell-surface associated apolipoprotein E from HepG2 cells. J. Lipid Res. 34:190-200.

62. Ji, Z. S., S. Fazio, Y. L. Lee, and R. W. Mahley. 1994. Secretion-capture role for apolipoprotein $\mathrm{E}$ in remnant lipoprotein metabolism involving cell surface heparin sulfate proteoglycans. J. Biol. Chem. 269:2764-2772.

63. Ji, Z. S., S. Fazio, and R. W. Mahley. 1994. Variable heparan sulfate proteoglycan binding of apolipoprotein $\mathrm{E}$ variants may modulate the expression of type III hyperlipoproteinemia. J. Biol. Chem. 269:13421-13428. 